\title{
PENYELESAIAN SENGKETA HUKUM TERHADAP PEMEGANG SERTIFIKAT HAK MILIK DENGAN ADANYA PENERBITAN SERTIFIKAT GANDA
}

\author{
Agus Salim \\ Magister Hukum Universitas Semarang, Semarang \\ agussalim@gmail.com
}

\begin{abstract}
ABSTRAK
Tujuan penelitian ini adalah untuk mengetahui dan menganalisas penyelesaian sengketa hukum terhadap pemegang sertifikat hak milik. Sertifikat ganda atau tumpang tindih atas satu bidang tanah yang sama, maka salah satu harus dibatalkan. Permasalahan dalam penelitian ini adalah faktor-faktor penyebab terjadinya sertifikat ganda, penyelesaian kasus sertifikat ganda yang terjadi serta upaya-upaya yang dilakukan untuk mencegah terjadinya sertifikat ganda. Metode penelitian yang digunakan dalam penulisan ini adalah metode penelitian kualitatif dengan pendekatan yuridis normativf. Berdasarkan hasil penelitian menunjukkan bahwa terjadinya sertifikat ganda disebabkan beberapa faktor, yaitu adanya itikad tidak baik dari pemohon sertifikat, adanya kesalahan dari pihak Kantor Pertanahan yaitu dalam hal pengumpulan dan pengolahan data fisik dan data yuridis tanah, belum tersedianya peta pendaftaran tanah secara menyeluruh, dan karena domisili pihak yang berkepentingan berada di luar kota. Penyelesaian sengketa pertanahan dapat diselesaikan dengan cara musyawarah oleh para pihak dan melalui peradilan. Pada sisi lain perlu adanya ketentuan hukum acara khusus baik melalui musyawarah atau mediasi di BPN dan pengadilan apabila terjadi penyelesaian sengketa melalui litigasi.
\end{abstract}

Kata kunci: Penyelesaian sengketa hukum; sertifikat tanah; ganda 


\title{
COMPLETION OF LEGAL DISPUTES AGAINST HOLDERS OF CERTIFICATE OF RIGHTS CERTIFICATE WITH DOUBLE PUBLISHING
}

\author{
Agus Salim \\ Master of Law, University of Semarang, Semarang \\ agussalim@gmail.com
}

\begin{abstract}
The purpose of this study is to find out and analyze the resolution of legal disputes against holders of certificates of ownership. Double or overlapping certificates over one plot of land, then one must be canceled. The problem in this research is the factors that cause the double certificate, the double certificate case settlement that occurs as well as the efforts made to prevent the double certificate. The research method used in this paper is a qualitative research method with normative juridical approach. Based on the results of the study indicate that the occurrence of multiple certificates caused by several factors, namely the bad intention of the applicant for the certificate, an error from the Land Office, namely in terms of collecting and processing physical data and juridical data of the land, the unavailability of a comprehensive land registration map, and because domicile of interested parties is outside the city. Settlement of land disputes can be resolved by deliberation by the parties and through justice. On the other hand there is a need for special procedural law provisions either through deliberation or mediation at BPN and the court if dispute resolution occurs through litigation.
\end{abstract}

Keywords: Settlement of legal disputes; land certificate; double 


\section{A. PENDAHULUAN}

Undang-Undang Pokok Agraria (UUPA) adalah Undang- Undang Nomor 5 Tahun 1960 tentang Peraturan Dasar Pokok-Pokok Agraria bertujuan untuk menyelesaikan konflik dualisme hukum agraria di Indonesia pada saat itu, dimana sebelumnya sebagian besar masyarakat Indonesia masih memberlakukan hukum agraria berdasarkan hukum barat (kolonial) dan sebagian kecil lainnya berdasarkan hukum adat.

Lahirnya UUPA, sebagai hukum agraria nasional diharapkan memberikan kepastian hukum bagi seluruh rakyat dan memungkinkan tercapainya fungsi bumi, air dan ruang angkasa serta kekayaan alam sebagaimana yang dicita-citakan tersebut.

Ketentuan tentang kepastian hukum hak atas tanah ini diatur dalam Peraturan Pemerintah Nomor 10 Tahun 1961 tentang Pendaftaran Tanah. Kemudian sesuai dengan dinamika dalam perkembangannya, Peraturan Pemerintah tersebut disempurnakan dengan Peraturan Pemerintah Nomor 24 Tahun 1997 tentang Pendaftaran Tanah. Peraturan pemerintah terbaru ini dilakukan penyederhanaan persyaratan dan prosedur untuk penyelenggaraan pendaftaran tanah. Kepastian hukum mengenai hak-hak atas tanah sebagaimana yang diamanatkan PP tersebut memberikan kenyamanan atas hak-haknya, dengan adanya perlindungan hukum yang sangat membantu masyarakat dari permasalahan sengketa tanah.

Bentuk perlindungan Hukum terkait tentang hak atas tanah adalah sertifikat atau hak milik atas tanah yang dimiliki. Fenomena yang terjadi di masyarakat pada beberapa daerah terdapat sejumlah kasus "sertifikat ganda", yaitu sebidang tanah terdaftar dalam 2 (dua) buah sertifikat yang secara resmi sama- sama diterbitkan oleh Kantor Pertanahan Kabupaten/Kota. Akibat dari terbitnya sertifikat ganda tersebut menimbulkan sengketa perdata antar para pihak, untuk membuktikan jaminan kepastian hukum atas tanah tersebut diselesaikan melalui lembaga peradilan.

Masalah pertanahan merupakan salah satu sektor pembangunan yang memerlukan penanganan yang amat serius dan ekstra hati-hati dari Pemerintah. Diperlukannya ekstra kehati-hatian ini karena permasalahan tanah sejak dahulu 
hingga sekarang merupakan persoalan hukum yang sangat pelik dan kompleks. Salah satunya adalah adanya sertifikat ganda atas tanah, yang mana sebidang tanah memiliki dua sertifikat tanah oleh dua orang yang berbeda.

Terbitnya dua sertifikat atas tanah atas sebidang tanah dapat menimbulkan suatu permasalahan hukum, mengingat sertifikat memiliki fungsi sebagai alat bukti hak atas tanah maupun hak tanggungan, dan sedangkan pemilik asli tanah dengan sertifikat ganda tersebut juga perlu diberikan jaminan hukum serta perlindungan hukum.

\section{B. PERMASALAHAN}

1. Bagaimana terjadinya sengketa hukum terhadap pemegang sertifikat ganda?

2. Bagaimana kendala dan solusi atas penyelesaian sengketa hukum sertifikat ganda?

\section{METODE PENELITIAN}

Sajian Metode Penelitian disistematiskan dengan format Metode Pendekatan; Spesifikasi Penelitian; Sumber dan Jenis Data; Teknik Pengumpulan Data; dan Teknik Analisis Data.

1) Metode Pendekatan: penelitian hukum normatif (legal research).

2) Spesifikasi Penelitian: Sifat penelitian ini adalah deskriptif analisis.

3) Sumber dan Jenis Data: Data Primer merupakan data peraturan perundangundangan yang telah ada dan berkaitan dengan penelitian ini; dan Data Sekunder merupakan bahan hukum sekunder berupa buku, artikel, laporan penelitian dan/ atau referensi lainnya.

4) Teknik Pengumpulan Data: Pengumpulan data-data primer dimulai dari undangundang yang relevan selanjutnya peraturan pemerintah, peraturan presiden, hingga peraturan menteri yang terkait dengan fokus penelitian. Pengumpulan data-data sekunder dilakukan sesuai dengan kebutuhan teoritik khususnya perihal teori-teori hukum.

5) Teknik Analisis Data: Analisis Hukum; dan analisis preskriptif. 
e-ISSN : 2621-4105

\section{PEMBAHASAN}

\section{Terjadinya Sengketa Hukum Terhadap Pemegang Sertifikat Ganda.}

Kepastian hukum mengenai hak-hak atas tanah sangatlah penting, sebagaimana amanat UUPA mengandung dua dimensi yaitu kepastian obyek hak atas tanah dan kepastian subyek hak atas tanah, yaitu kepastian letak bidang tanah yang berkoordinat geo-referensi dalam suatu peta pendaftaran tanah dan kepastian subyek diindikasikan dari nama pemegang hak atas tanah tercantum dalam buku pendaftaran tanah pada instansi pertanahan, dimana salinan dari peta dan buku pendaftaran tanah tersebut dikenal dengan sebutan Sertifikat Tanah.

Sertifikat hak atas tanah sebagai hasil akhir proses pendaftaran hak atas tanah termasuk perubahan-perubahan menyangkut subyeknya, status haknya dan perbuatan-perbuatan hukum yang dilakukan terhadap tanahnya merupakan alat pembuktian yang kuat sebagaimana dinyatakan dalam ketentuan Pasal 19 ayat (1) huruf c, Pasal 23 ayat (2), Pasal 32 ayat (2) dan Pasal 38 ayat (2) UUPA.

Sertifikat merupakan tanda bukti yang kuat dan bukan merupakan tanda bukti yang mutlak/sempurna menurut ketentuan UUPA dan Peraturan Pemerintah yang melaksanakannya (PP Nomor 10 Tahun 1961 dan PP Nomor 24 Tahun 1997). Hal ini berarti bahwa keterangan- keterangan yang tercantum di dalamnya mempunyai kekuatan hukum dan harus diterima (oleh hakim) sebagai keterangan yang benar selama dan sepanjang tidak ada alat pembuktian yang membuktikan sebaliknya. ${ }^{1}$

Dalam Pasal 32 ayat (1) Peraturan Pemerintah Nomor 24 Tahun 1997 disebutkan bahwa sertifikat merupakan tanda bukti hak yang berlaku sebagai alat pembuktian yang kuat, namun pada ayat (2) pasal tersebut menyebutkan apabila diatas suatu bidang tanah yang sudah diterbitkan sertifikat secara sah atas nama orang atau badan hukum yang memperoleh tanah tersebut dengan itikad baik dan secara nyata menguasainya, maka pihak lain yang merasa mempunyai hak atas tanah itu tidak lagi dapat menuntut pelaksanaan hak tersebut apabila dalam waktu 5 (lima) tahun sejak diterbitkannya sertifikat itu tidak mengajukan keberatan secara tertulis kepada pemegang sertifikat dan Kepala Kantor Pertanahan yang bersangkutan

${ }^{1}$ Arie S. Hutagalung, Tebaran Pemikiran Seputar Masalah Hukum Tanah, cet. 1, (Jakarta: LPHI, 2005), hal 81. 
ataupun tidak mengajukan gugatan ke Pengadilan mengenai penguasaan tanah atau penerbitan sertifikat.

Ada beberapa hal yang dapat menyebabkan terjadinya sertifikat ganda tersebut, diantaranya yaitu:

a. Sertifikat dimaksud tidak dipetakan di dalam peta pendaftaran tanah, atau peta situasi dari daerah tersebut, serta belum adanya peta tunggal.

b. Istilah peta tunggal tidak terdapat dalam Peraturan Pemerintah Nomor 24 Tahun 1997 adalah merupakan istilah yang sering digunakan pada teknis pengukuran.

c. Peta tunggal adalah peta yang terdiri dari peta fotogrametri, peta kerja, peta garis, peta pendaftaran tanah yang digabung menjadi satu.

Kasus sertifikat hak atas tanah ganda dapat terjadi karena beberapa hal sebagai berikut: $^{2}$

a. Sewaktu dilakukan pengukuran atau penelitian di lapangan, pemohon dengan sengaja menunjukkan letak tanah dan batas-batas tanah yang salah.

b. Adanya surat bukti atau pengakuan hak yang ternyata terbukti mengandung kesengajaan/ketidakbenaran/kepalsuan dan atau tidak berlaku lagi.

c. Untuk wilayah bersangkutan belum tersedia peta pendaftaran tanahnya.

d. Sertifikat ganda juga dapat terjadi didukung karena timbulnya kesalahan administasi.

Kantor Pertanahan bersangkutan seharusnya memastikan siapa pemilik tanah, letak, batas, patok tanah, tersebut dengan memanggil para pemilik tanah serta para pemilik tanah yang berbatasan dengan tanah si pemohon sehingga tidak terjadi kecurangan maupun kelebihan atau kekurangan yang mengakibatkan kerugian bagi pihak-pihak tersebut. Pengukuran dan penelitian tersebut adalah jenis data yang diperlukan untuk kepastian suatu bidang tanah, yang terdiri atas:

a. Data Fisik (fisik tanah), mengenai tanahnya, yaitu letak/lokasi, batas-batasnya, luasnya bangunan dan tanaman yang ada diatasnya. Jadi berpatok pada letak, batas, dan luas (ada atau tidak bangunan diatasnya).

${ }^{2}$ Supranowo, "Sertipikat dan Permasalahannya", (Makalah disampaikan pada Seminar Nasional Kegunaan Sertipikat dan Permasalahannya, Yogyakarta, 9 Juli 1992), hlm. 10. 
b. Data Yuridis (yuridis tanah), mengenai haknya; siapa pemilik/pemegang haknya, kategori status hak tanah, ada atau tidak adanya hak-hak pihak lain yang membebani.

Jadi berpatok pada status tanah, subyek, dan hak-hak lain yang ada diatasnya. Pengumpulan data fisik dan data yuridis sebagaimana diatur dalam Pasal 14 dan Pasal 23 Peraturan Pemerintah Nomor 24 Tahun 1997 harus diterapkan dalam proses terbitnya sertifikat. Prosedur pengumpulan data fisik dan yuridis ini guna menjamin kepastian hukum di bidang penguasaan dan pemilikan tanah faktor kepastian letak dan batas setiap bidang tanah, sehingga dapat menghindari tumpang tindih yang mengakibatkan sertifikat ganda.

Dalam beberapa kasus terjadi pada Kantor Pertanahan di berbagai kota/kabupaten. Kantor Pertanahan tersebut dengan ketidaaktelitiannya menerbitkan sertifikat Hak Milik dengan pemohon yang diajukan oleh pemilik tanah, yang mana termasuk salah satu pemegang hak bersama dari hak atas bidang tanah hak milik sertifikat. Sebagaimana diatur dalam Pasal 3 huruf d Peraturan Presiden Republik Indonesia Nomor 10 Tahun 2006 Tentang Badan Pertanahan Nasional, bahwa salah satu fungsi dari Badan Pertanahan Nasional adalah pembinaan dan pelayanan administrasi umum di bidang pertanahan. Dengan adanya fungsi yang jelas maka akan terselenggara pendaftaran tanah yang efektif dan teratur akan menjadikan tertib administrasi pertanahan. Pelaksanaan administrasi pertanahan yang dijalankan pemerintah yang dilaksanakan oleh Badan Pertanahan Nasional. Dalam pelaksanaan administrasi tersebut terdapat unsur catur tertib. Sasaran utama dari catur tertib pertanahan adalah dalam rangka terwujudnya tujuan dari Ketetapan Majelis Permusyawaratan Rakyat Nomor II/MPR 1998 tentang Garis-garis Besar Haluan Negara yang menitikberatkan kepada penataan pemilikan, penggunaan dan penguasaan tanah bagi masyarakat secara adil dan peningkatan kualitas lingkungan serta sumber daya alam yang dimiliki.

Adapun jenis pemalsuan sertifikat di antaranya adalah:

a. Penggandaan sertifikat yang asli. Modus operandinya adalah:

1) Sertifikat asli difoto copy kemudian isinya disalin kedalam blanko sertifikat yang palsu 
2) Tanda tangan pejabat dan cap dipalsukan.

3) Seluruh isi disalin dari foto copy sertifikat.

b. Mengubah sebagian atau seluruhnya isi dari sertifikat yang asli, yang tidak sesuai dengan ketentuan yang berlaku. Modus operandinya adalah: Nama pemegang hak, luas tanah dan nomor hak pada sertifikat diubah.

c. Menggunakan blanko sertifikat yang prosesnya belum tuntas, baik yang sudah atau yang belum ditandatangani pejabat. Modus operandinya adalah:

1) Nama pemegang hak tidak diubah, sedangkan nama desa dan kecamatan diubah serta luas tanah pada umumnya diubah menjadi lebih besar.

2) Buku tanah dan Gambar Situasi/Surat Ukur yang ada di

3) Tanda tangan pejabat ada yang dipalsukan dan ada yang asli, sedangkan isi sertifikat tidak diubah.

d. Menggunakan sampul blanko sertifikat yang sah dari kantor lain dan digunakan di dalam atau di luar wilayah kantor lainnya. Modus operandinya adalah: Oleh pihak lain tersebut sampulnya dicopot dan isinya diganti dengan lembaran blanko lain dan isi sertifikat dipalsukan.

e. Menggunakan blanko palsu yang dicetak di luar. Modus operandinya adalah: Blanko maupun isi dan tanda tangan pejabat dipalsukan

f. Mengubah sertifikat yang sudah dimatikan. ${ }^{3}$ Modus operandinya adalah: Sertifikat yang sudah dimatikan, dihapus / dihilangkan sehingga seolah-olah seperti sertifikat yang masih berlaku. Pada buku tanah sudah dicatat dimatikan ${ }^{4}$.

Melalui munculnya sertifikat ganda, maka kedudukan sertifikat ganda harus ditinjau ulang. Pada kasus sertifikat ganda di Makassar dan telah diajukan ke Pengadilan Tata Usaha Negara Makassar dan dalam keputusan yang ditetapkan bahwa tidak terjadi pembatalan atau pencabutan, sehingga menyebabkan kedudukan sertifikat ganda menjadi status quo. Penulis menilai bahwa Kantor Pertanahan Kota Makassar tidak cermat, teliti, sehingga perlu ditinjau ulang keberadaan sertifikat Hak Milik 1361 tanggal 8 April 2004 tersebut, karena tidaklah mungkin serta merta kedua sertifikat tersebut berlaku. Terdapat cacat hukum dalam sertifikat ganda ini.

\footnotetext{
${ }^{3}$ Loebby Loqman, loc.cit., hlm. 32.

${ }^{4}$ Loebby Loeqman, Op.cit., hlm. 45.
} 
Dalam hal ini kita melihat bahwa prinsip yang diambil adalah agar berbeda daripada apa yang biasanya terjadi dengan penerbitan dari sertifikat ganda atas satu bidang tanah diterbitkan 2 (dua) sertifikat. Dalam hal jurisprudensi sertifikat ganda ini, biasa dinyatakan bahwa sertifikat yang diterbitkan lebih dahulu adalah yang sah, sedangkan yang diterbitkan kemudian adalah yang tidak mempunyai kekuatan hukum.

Kantor Pertanahan selaku instansi yang menerbitkan harus benar-benar menelusuri adanya cacat hukum yang bisa timbul yang diakibatkan oleh instansi tersebut, sehingga tidak merugikan para pemilik hak atas tanah. Pasal 1 huruf $b$ Keputusan Menteri Negara Agraria/Kepala Badan Pertanahan Nasional Nomor 10 Tahun 1993 Tentang Tata Cara Penggantian Sertifikat Hak Atas Tanah mendefinisikan sertifikat lama sebagai berikut: "Sertifikat lama adalah sertifikat yang telah diterbitkan oleh Kantor Pendaftaran Tanah, Kantor Pendaftaran dan Pengawasan Pendaftaran Tanah, Kantor Sub Direktorat Agraria, Kantor Agraria dan Kantor Pertanahan Kabupaten/Kotamadya sebelum ditetapkannya Keputusan Kepala Badan Pertanahan Nasional Nomor 14 Tahun 1989." Sedangkan definisi sertifikat baru menurut Pasal 1 huruf c Keputusan Menteri Negara Agraria/Kepala Badan Pertanahan Nasional Nomor 10 Tahun 1993 Tentang Tata Cara Penggantian Sertifikat Hak Atas Tanah mendefinisikan sebagai berikut: "Sertifikat baru adalah adalah sertifikat yang telah diterbitkan oleh Kantor Pertanahan Kabupaten/Kotamadya dengan menggunakan blanko sertifikat sebagaimana ditetapkan dengan Keputusan Kepala Badan Pertanahan Nasional Nomor 14 Tahun 1989. “

Pada hakikatnya kedudukan hukum sertifikat adalah kuat dimata hukum, akan tetapi dengan timbulnya sertifikat lain pada sebidang tanah sertifikat menjadi lemah. Bahwa sertifikat atas tanah ganda tersebut secara yuridis tidak dapat berlaku sebagai alat pembuktian yang sah, sehingga dengan terjadinya kasus sertifikat ganda ini tidak dapat memberikan perlindungan hukum sepenuhnya kepada pemilik dan pemegang hak atas tanah.

Untuk kedudukan sertifikat ganda jika status dari suatu tanah adalah status quo dan tidak ada perintah dari pengadilan serta tidak ada putusan pembatalan, 
maka pembukuan dalam buku tanah akan mencantumkan catatan mengenai adanya sengketa dan hal-hal yang disengketakan.

\section{Kendala Dan Solusi Atas Penyelesaian Sengketa Hukum Sertifikat Ganda.}

Sertifikat memberikan kekuatan pembuktian bagi pemilik hak atas tanah yang namanya tercantum dalam sertifikat, kecuali adanya cacat data fisik maka kekuatan hukum sertifikat akan hilang. Dengan adanya cacat yuridis dan cacat data fisik sehingga dapat menimbulkan sertifikat ganda hal ini terjadi pada sertifikat yang tidak dipetakan dengan tidak benar di dalam peta pendaftaran tanah oleh Kantor Pertanahan setempat.

Munculnya sertifikat ganda dalam beberapa kasus timbul karena para pihak selaku pemilik hak atas tanah melakukan pengaduan dan keberatan sebagai pihak yang dirugikan dengan munculnya sertifikat pada obyek yang sama dengan nomor yang sama tetapi pengeluaran tanggal yang berbeda tahun, sedangkan untuk surat ukur/gambar situasi dengan nomor dan tanggal yang sama, serta luas tanah yang sama. Para pemegang pemilik hak atas tanah merasa dirugikan sehingga mengajukan tuntutan terhadap Keputusan Tata Usaha Negara dibidang pertanahan yang telah dikeluarkan oleh Kepala Kantor Pertanahan, dimana dengan keluarnya keputusan Kantor Pertanahan tersebut sudah merugikan hak-hak pemilik atas tanah tersebut.

Terhadap beberapa kasus sertifikat ganda pada sertifikat Hak Milik terdapat juga kesalahan atau cacat administrasi yang mengakibatkan cacat hukum pada sertifikat yang muncul dengan nama pemilik yang sama, obyek yang sama, dan luas yang sama, terlebih para pemilik hak atas tanah tidak pernah meminta kepada Kepala Kantor Pertanahan untuk menerbitkan sertifikat baru ataupun memberi kuasa kepada orang lain. Hendaknya terlebih dahulu Kantor Pertanahan mengecek atau memeriksa secara rinci terhadap sertifikat yang dikeluarkannya tersebut untuk mengetahui penyebab kesalahan yang terjadi sehingga timbulnya sertifikat ganda, serta untuk mencari langkah-langkah apa saja yang harus diambil untuk meminimalisir kerugian dari para pemilik hak atas tanah terutama kepada pemilik sertifikat Hak Milik yang sesungguhnya. 
Penyelesaian melalui Pengadilan, dilakukan apabila usaha-usaha musyawarah tersebut mengalami jalan buntu, atau ternyata ada masalah- masalah prinsipil yang harus diselesaikan oleh instansi lain yang berwenang, misalnya pengadilan, maka kepada yang bersangkutan disarankan untuk mengajukan masalahnya ke pengadilan. Jadi pada umumnya sifat dari sengketa ini adalah karena adanya pengaduan yang mengandung pertentangan hak atas tanah maupun hak-hak lain atas suatu kesempatan/ prioritas atau adanya suatu ketetapan yang merugikan dirinya. Pada akhirnya penyelesaian tersebut, senantiasa harus memperhatikan/selalu mendasarkan kepada peraturan yang berlaku, memperhatikan keseimbangan kepentingan- kepentingan para pihak, menegakkan keadilan hukumnya serta penyelesaian ini diusahakan harus tuntas. Penyelesaian sengketa melalui pengadilan merupakan bentuk penyelesaian sengketa yang menghasilkan keputusan (vonnis) yang bersifat membenarkan atau menyalahkan salah satu pihak yang berperkara. Hal tersebut di atas terjadi karena pengadilan diberi kekuasaan untuk menetapkan siapa yang benar dan salah. Pada sisi yang lain penyelesaian sengketa di luar pengadilan (dalam sistem hukum adat) yang didasarkan pada kekuatan kultur berorientasi pada perdamaian dan keselarasan dalam kehidupan masyarakat. Cara penyelesaian demikian tidak menimbulkan konsekuensi adanya pihak yang salah dan benar dan tetap menjaga hubungan baik antar pihak yang bersengketa. Aspek-aspek yang mempengaruhi pilihan tindakan dalam penyelesaian suatu sengketa yang berupa faktor-faktor yang mempengaruhi perilaku, makna, dan tujuan, sebagaimana tersebut di muka pada dasarnya tidaklah berdiri sendiri. Ketiga aspek tersebut bagi tindakan seseorang mempunyai kaitan satu sama lain. Pengunaan suatu kelembagaan penyelesaian sengketa tertentu selain mempunyai tujuan tertentu yang diharapkan, juga sekaligus mempunyai makna tertentu atas tindakannya tersebut. Di samping ada keterkaitan hubungan antara tujuan dan perhitungan untung rugi, ada juga keterkaitan hubungan antara pilihan tindakan yang diambil dengan konsekuensi yang akan terjadi. 
Penyelesaian sengketa melalui pengadilan bukanlah suatu paksaan oleh karena undang-undang membolehkan pihak yang bersengketa menyelesaikan sengketa di luar pengadilan dengan cara perdamaian.

\section{E. PENUTUP}

Terjadinya sengketa hukum terhadap pemegang sertifikat hak milik dengan adanya penertiban sertifikat ganda, dikarenakan adanya kepentingan untuk menguasai objek tanah dengan cara melanggar hukum seperti penipuan, jual beli fiktif, pemalsuan sertifikat dan penggandaan sertifikat dengan berbagai modus. Selain itu juga didukung lemahnya kinerja aparat BPN, terutama kurang teliti / cermat dalam meneliti administrasi permohonan penertiban sertifikat.

Kendala yang dihadapi dalam penyelesaian sengketa hukum terhadap pemegang sertifikat hak milik dengan adanya sertifikat ganda adalah dikarenakan :

Putusan Peradilan TUN tidak tegas dalam pembatalan sertifikat yang dianggap cacat hukum, berakibat kedudukan tanah menjadi status quo dan tidak ada perintah dari pengadilan serta tidak ada putusan pembatalan, maka pembukuan dalam buku tanah akan mencantumkan catatan mengenai adanya sengketa dan hal-hal yang disengketakan. Sertifikat hak atas tanah yang tidak dapat dibuktikan kepalsuan dari sertifikat tersebut, maka sertifikat adalah sah dan menjadi jaminan kepastian dan perlindungan hukum bagi pemegang hak atas tanah. Sedangkan bagi pihak yang melakukan perbuatan hukum atas sertifikat ganda, yang dalam kasus ini pengalihan haknya melalui jual beli, sepanjang perolehan haknya telah memenuhi ketentuan dan prosedur berdasarkan peraturan perundang-undangan yang berlaku, dan telah melakukan balik nama, sehingga nama yang tertera dalam sertifikat tersebut adalah namanya, maka sertifikat tersebut memberikan kepastian dan perlindungan hukum baginya. Selain itu, mengenai pembuktian peralihan hak atas tanah, akta jual beli yang dibuat oleh PPAT adalah akta otentik yang dapat dijadikan sebagai alat bukti yang kuat dipersidangan. Penyelesaian terhadap sertifikat ganda dalam kasus selama ini dapat dilakukan bebarapa cara. Pertama yang ditempuh adalah dengan jalan musyawarah yang ditempuh oleh para pihak yaitu pemegang hak selaku penggugat dan Kantor Pertanahan selaku tergugat. Apabila tidak dapat ditempuh jalan musyawarah, Kantor Pertanahan dapat melakukan penyelesaian secara sepihak 
e-ISSN : 2621-4105

dengan meninjau ulang atas terbitnya sertifikat ganda yang telah dikeluarkan yang disebabkan kesalahan administrasi dan kesalahan penunjukan letak tanah serta batas-batas. Hasil peninjauan tersebut dapat ditindaklanjuti dengan melakukan pembatalan sertifikat yang sejatinya dapat diputuskan oleh Badan Pertanahan Nasional. Kesimpulannya ketentuan tersebut harus diatur dengan jelas melalui hukum acara penyelesaian sengketa atas terjadinya sertifikat ganda. 


\section{DAFTAR PUSTAKA}

\section{Buku}

A P. Parlindungan. Pendaftaran Tanah Di Indonesia. Bandung: Mandar Maju, 1990.

Basuki, Sunario. Hukum Tanah Nasional Landasan Hukum Penguasaan Dan Penggunaan Tanah, (Diktat Mata Kuliah Hukum Agraria, Magister Kenotariatan Fakultas Hukum Universitas Indonesia, Depok), 2002.

Bosu, Benny. Perkembangan Terbaru Sertifikat. Jakarta: Departemen Pekerjaan Umum, 1997.

Blitanagy, Josef, Johanes. Hukum Agraria Nasional. Ende Flores: Nusa Indah, 1984.

Effendie, Bachtiar. Pendaftaran Tanah di Indonesia dan Peraturan Pelaksanaannya, Cet. I, Bandung: Alumni, 1993.

Gautama, Sudargo. Tafsiran Undang-Undang Pokok Agraria (1960) dan PeraturanPeraturan Pelaksananya (1996). Bandung: Citra Aditya Bakti, 1997.

Harsono, Boedi. Hukum Agraria Indonesia Sejarah Pembentukan Undang- Undang Pokok Agraria, Isi dan Pelaksanaanya. Jakarta: Djambatan, 2005.

Jaminan Kepastian Hukum, Jakarta: Pustaka Peradilan Jilid X, Mahkamah Agung RI, 1998.

Kasus - Kasus Pengadilan Tanah dalam Putusan Pengadilan. Jakarta: Pustaka Peradilan Jilid X Mahkamah Agung RI, 1998.

Hermit, Herman. Cara Memperoleh Sertifikat Tanah Hak Milik, Tanah Negara dan Tanah Pemda. Bandung: Mandar Maju, 2004.

Hutagalung, Arie S. Serba Aneka Masalah Tanah Dalam Kegiatan Ekonomi (suatu kumpulan karangan). Jakarta: Badan Penerbitan Fakultas Hukum UI, 1999.

Tebaran Pemikiran Seputar Masalah Hukum Tanah. Jakarta: Lembaga Pemberdayaan Hukum Indonesia, 2005.

Lubis, Mhd Yamin \& Lubis, Abd. Rahim. Hukum Pendaftaran Tanah. Jakarta: Mandar Maju, 2008.

Loqman, Loebby. Laporan Akhir Analisis dan Evaluasi Hukum Tentang Penanggulangan dan Penyelesaian Sertifikat Bermasalah. Jakarta: Badan

Pembinaan Hukum Nasional

Departemen Kehakiman, 1995. 